\title{
On a certain style of history that is not ours. Lucien Febvre.
}

Camille Akmut (trans., int.)

December 30, 2019

\begin{abstract}
"Sur une forme d'histoire qui n'est pas la notre". 1948. Content : obscure, but eternal historian lambasted by Febvre.
\end{abstract}




\section{Introduction : scientists without programs}

The following was published 4 years after the death of Marc Bloch, who had written to Febvre in an earlier letter : "My life continues to mean very little to me..." ${ }^{1}$, before joining one last battle whose outcome was his execution by the Germans in 1944;

Bloch and Cavailles must have seen much worse, in their last months, than fathers being killed in front of sons, like in the Aeneid, noble readings of distant colleage years...

Febvre, who remained, had become - by default - the leader and main voice of the post-War Annales school :

Febvre was seventy years old when "On a [form] of history that is not ours" appeared. Men and women half his age couldn't find the courage to write even half - lacking also the capacities.

At a certain University, former "intellectual center of Europe", a Professorson-of-a-Professor had gone on and on about the great injustices he had suffered : the local National Academy had not answered his application... (His mother had gotten him a job once, but not twice...)

It is perhaps exactly people like him that Febvre had in mind when writing this text. Particular, and eternal.

These intellectuals-in-name-only (three quarters "hustlers", and thinkers of little talents with what remains) are easily identified : careers, promotions, titles, conferences and networks are more important to them than their science. By these signs they give themselves away; finding the latter considerably harder to undertake, and face honestly.

The scientific part of their existence : an uncomfortable, and frankly inconvenient $a d$-hoc occupation...

\footnotetext{
${ }^{1}$ Previous issue of Annales.
} 


\section{INTELLECTUAL FIGHTS, AND OTHERS \\ ("DEBATS ET COMBATS")}

\section{On a certain style of history that is not ours.}

$(\ldots)$

"Of all idiocies faithfulness to oneself is the greatest, as soon as not spontaneous anymore", Gides wrote in Pretextes.

As such nothing more legitimate - being spontaneous - than the faithfulness of Charlemagne's historian to his own ideas : (...) a certain style of history which Henri Berr had fortunately coined "historicizing history". Louis Halphen has given his entire life to it. This historian graces us today with an Introduction to History, but to be sure this contribution is not one to universal Clio, under whose peplos a great variety, a great diversity of historical schools hide, just as the Virgin of Mercy harbors all worthy representatives of Christianity.

More modest, and more proud [arrogant], Halphen only thinks of one kind of history : his own! What honor he makes us to think that we should embrace it as the only one valid. "Introduction to history"? "Defense of the historical discipline?" No;

Rather advocacy of this "historicizing history" of which Berr had already written, in 1911 : "we are dealing here with a form of history that - self-sufficient - also believes to be all of historical knowledge."... Such sentences fill me with great pleasure. It ought to be enough to serve as summary for this [little] book.

But, who is this historicizing historian?

To use the words of Halphen, found in a letter from 1911 to Berr : a man who, working on particular facts established by themselves, proposes to connect them, to coordinate them, in an attempt to -quote on quote"analyze the political, social and moral changes that these texts reveal to us at a given moment in time." For our author, history is a science of the particular. - this goes without saying.

Now, let's open this "Introduction to History" from 1946 : chapter I. The establishment of facts. II The orchestration of facts. III. A report of the facts.

History like in the days of Thucydides or Herodotus! That good, old doctrine... Fustel and Mommsen [would have applauded, and] wouldn't have done any better, or different. And, so it remains done today. Sure. But, establishing facts before putting them into motion : here is one of those formulas [or equations] which leave anxious and flabbergasted [astounded] the curious mind.

These facts. What do you call facts? Do you think of them as being given to history as substantial realities, only covered by time and dust? 
Ready to be uncovered by historians... To be put on display under best lights for contemporaries?

(...) Berthelot was wrong when he said of his young science - just having reached its first results - that it "fabricated its objects". All sciences fabricate their objects.

[In the minds of these idiotic historians : Aulard, Seignobos, Langlois, their contemporaries, and successors] (completely ignorant of the practices and methods of sciences) a histologist is someone who splits rat brains open, at which point finally "the facts" are revealed. "Ready, baked" if I'm allowed to say. Ready to be put inside cupboards.

They would have [fallen from their chairs] had they been told that a histologist, in fact, with a variety of intricate techniques and subtle colorants, fabricates first. A "revelation" [of facts] occurs, but only in a photographic sense. After which only they start interpreting.

(...)

And, they would be surprised too, to know that - as a contemporary philosopher put it - "facts are merely a nail on which to hang theories". But, these nails we must forge them first. And, as for history, it is the historian who creates them.

It is not, as he says, "the Past", or - in a tautology - "the History".

Do you agree? Do you disagree? Then make it known, but by all gods don't silence such discussions! This major, capital problem.

This silence is what separates us [from them]. But it is only the first of many, and of many consequences!

Have you ever heard [these authoritative historians] say : "THE HISTORIAN CANNOT CHOOSE FACTS." But, by what right? What principles? Choosing [, in their minds,] becomes a terrorist act, against "reality", hence "truth".

(...)

We must collect all facts. Let's not choose. - our old masters said.

In fact, history is a choice. Arbitrary, it is not. Planned? Yes. [It is a choice for a certain style of history, too.]

Hypotheses, programs of research [and outlines], theories even : one would look for them in vain in their works.

(...)

"Like a rag-and-bone man finding useful items with every step" (as a precursor of Claude Bernard had said) - these historians are just like them.

Historians without programs.

(...)

You remind me of these poor people - lecturers at universities - who used to be in charge of teaching mathematics at lower levels, and under whose patronage that discipline had become a series of "clever tricks".

(...)

Instead they should have taught why it was useful, where it had come from, how it was discovered... Learning mathematics to gain entrance to 
[e.g. MIT or the here mentioned Ecole Polytechnique] is not an end in itself.

(..)

Poor history, this history. Its ambitions so little. 